\title{
ALTERNATIF PENYELESAIAN SENGKETA WILAYAH LAUT INDONESIA-MALAYSIA
}

\author{
Ayub Torry Satriyo Kusumo dan Handojo Leksono. \\ Fakultas Hukum Universitas Sebelas Maret \\ E-mail: ayub_satriyo@yahoo.com
}

\begin{abstract}
This study discusses alternative resolutions on maritime boundary dispute between Indonesia and Malaysia. It was based on a legal research, which used statutes and case approach. The research materials were collected by literature study and analyzed by applying the interpretation analysis technique.

The result shows that the alternative resolutions of Indonesia-Malaysia border dispute can be carried out through several mechanisms. First, by referring to the UNCLOS 1982, through Bilateral Mutual Agreement on drawing an equidistant line using the equity principle and considering relevant circumstances. Second, by means of ASEAN; and third, by means of International Court of Justice mechanism regarding the equitable principle and relevant circumstances.
\end{abstract}

Keywords: the outermost islands, border management, maritime dispute settlement, archipelagic state

\section{ABSTRAK}

Penelitian ini membahas alternatif penyelesaian sengketa batas maritim antara Indonesia dan Malaysia. Kajian ini berdasarkan penelitian hukum dengan menggunakan pendekatan undang-undang dan pendekatan kasus. Pengumpulan bahan hukum melalui studi kepustakaan dan dianalisis dengan teknik analisis interpretasi hukum.

Hasil pembahasan menunjukkan alternatif penyelesaian sengketa batas wilayah Indonesia-Malaysia dapat dilakukan dengan beberapa cara. Pertama, mengacu pada UNCLOS 1982 melalui Bilateral Mutual Agreement dalam menarik garis sementara yang menggunakan prinsip sama jarak dan mempertimbangkan faktor yang relevan, kedua, melalui mekanisme ASEAN, dan ketiga, melalui mekanisme Mahkamah Internasional dengan mengedepankan equitable principle dan relevant circumstances.

Kata kunci : Pulau-pulau terluar, pengelolaan batas wilayah, penyelesaian sengketa maritim, negara kepulauan

\section{A. Pendahuluan}

The United Nations Convention on the Law of the Sea (UNCLOS) 1982 mengatur hukum laut internasional, yang di dalamnya mengatur perbedaan penetapan batas wilayah negara pantai dan negara kepulauan. Laut territorial suatu negara berjarak 12 mil, zona tambahan 24 mil, dan zona ekonomi eksklusif 200 mil diukur dari garis pangkal (base line). Batas wilayah negara kepulauan merupakan garis yang menghubungkan titik-titik yang ditarik tegak lurus dari pulau-pulau terluar atau titik-titik terluar negara tersebut. Sementara batas wilayah negara pantai merupakan garis sejajar lekuk-lekuk pantai. Adapun pengukuran jarak dilakukan pada saat air surut. Salah satu contoh negara kepulauan adalah Indonesia dan negara pantai adalah Malaysia. Penerapan UNCLOS 1982 menimbulkan masalah oleh kedua negara karena dekatnya posisi kedua negara sehingga adanya area yang tumpang tindih. Sampai saat ini masih banyak sengketa batas wilayah laut Indonesia-Malaysia belum terselesaikan. Permasalahan tersebut menyangkut hak eksplorasi, eksploitasi, pengeIolaan sumberdaya hayati maupun non hayati, dan

Yustisia Vol.2 No.1 Januari - April 2013 yurisdiksi negara. Oleh karena itu, dibutuhkan suatu solusi penyelesaian yang saling menguntungkan antara kedua negara. Tulisan ini membahas permasalahan, bagaimana alternatif penyelesaian sengketa wilayah laut Indonesia-Malaysia? Pembahasan alternatif penyelesaian sengketa wilayah laut Indonesia-Malaysia dengan memperhatikan konsep negara dan dasar yuridis Indonesia sebagai negara kepulauan, serta mekanisme penyelesaian sengketa internasional.

\section{B. Metode Penelitian}

Penelitian ini merupakan penelitian hukum normatif, dengan pendekatan perundang-undangan dan kasus. Bahan hukum primer meliputi United Nations Convention on the Law of the Sea 1982, Undang Undang No 2 Tahun 1971 tentang Perjanjian Garis Batas Laut Wilayah Indonesia-Malaysia, Keppres No 20 Tahun 1972 tentang Persetujuan Garis Batas Landas Kontinen antara IndonesiaMalaysia-Thailand, Keppres No 89 tahun 1969 tentang Persetujuan Garis Batas Landas Kontinen antara Indonesia dan Malaysia, dan putusan Mahkamah Internasional tentang Penyelesaian 
sengketa Pulau Sipadan dan Pulau Ligitan. Bahan hukum sekunder berupa semua publikasi nasional dan internasional tentang hukum laut internasional, artikel penulis yaitu pengelolaan pulau-pulau terluar, dan buku-buku teks pendukung lainnya. Teknik pengumpulan bahan hukum menggunakan studi pustaka dan studi dokumen, serta dianalisis dengan identifikasi fakta, interpretasi dan penalaran hukum secara sistematis, logis, dan yuridis.

\section{Hasil Penelitian dan Pembahasan}

\section{Konsep Wilayah Negara Menurut Hukum} Internasional

Pasal 1 Konvensi Motevideo 1933 mengenai hak-hak dan kewajiban-kewajiban negara, mengatur bahwa salah satu unsur negara adalah wilayah (Jawahir Thontowi, 2006 : 177). Konsep wilayah negara memberikan prinsip non-intervensi dalam persoalan yang mencakup yurisdiksi domestik dan prinsip untuk menghormati integritas wilayah negara lain (Malcolm N Shaw, 1997 : 330). Dalam perkembangannya, seringkali terjadi konflikkonflik yang bersumberkan pada masalah batas wilayah negara (Gillian Triggs, 2009 : 61). Meskipun wilayah merupakan salah satu unsur yang penting bagi suatu negara, dalam sejarah kehidupan negara-negara pernah terjadi bahwa suatu negara yang pada awal berdirinya belum memiliki batas-batas wilayah yang jelas. Negara-negara tersebut antara lain Israel pada waktu memproklamasikan kemerdekaannya pada tahun 1948 dan Palestina Merdeka yang memproklamasikan kemerdekaannya 15 November 1988, batasbatas wilayah negara sama sekali belum jelas. Bahkan pemerintahan Palestina masih berada di negara Tunisia, sebagai pemerintah dalam pengasingan namun sudah diakui sebagai sebuah negara berdaulat (I Wayan Parthiana, 2003 : 146). Contoh lainnya adalah negara Indonesia, yang memproklamasikan kemerdekaannya pada tanggal 17 Agustus 1945. Meskipun sudah diakui oleh beberapa negara yang dipelopori oleh Mesir, Belanda belum mengakui kemerdekaan dan kedaulatan Indonesia saat itu Belanda mengakui kedaulatan Indonesia secara bertahap. Pertama, berdasarkan Perjanjian Linggarjati 25 Maret 1947 yang berisi pengakuan Belanda atas kedaulatan Indonesia meliputi Sumatera, Jawa, dan Madura. Kedua, Belanda kemudian mengakui kedaulatan Indonesia yang meliputi Jawa Tengah, Yogyakarta, dan Sumatera berdasarkan Perjanjian Renville 17 Januari 1948. Ketiga, dalam Konferensi Meja Bundar (KMB) 23 Agustus - 2 November 1949, Belanda mengakui seluruh wilayah Indonesia kecuali Irian Barat. Pengakuan pemerintah Belanda ini ditandai dengan penyerahan kedaulatan dan penandatanganan hasil konferensi pada 27 Desember 1949 di Istana Dam Belanda (KML Tobing, 1987: 235). Keempat, Pengakuan Belanda atas Irian Barat sebagai bagian dari wilayah kedaulatan Indonesia terjadi setelah dilaksanakannya Bilateral Agreement dalam Perjanjian New York 15 Agustus 1962. Berdasarkan tahap-tahap di atas, dapat disimpulkan bahwa sesungguhnya pemerintah Belanda belum memberikan pengakuan terhadap kedaulatan Indonesia berdasarkan Proklamasi 17 Agustus 1945. Pemerintah Belanda baru mengakuinya pada 16 Agustus 2005 yang disampaikan secara resmi oleh Menteri Luar Negeri Belanda, Bernard Rudolf Bot melalui pidato kenegaraan di Kementerian Luar Negeri Indonesia.

\section{Dasar Yuridis Indonesia sebagai Negara} Kepulauan

a. Indonesia sebagai Negara Kepulauan

Usaha Indonesia untuk diakui sebagai negara kepulauan (archipelagic state) pertama kali tertuang dalam Deklarasi Djuanda (Mirza Satria Buana, 2007 : 105) tanggal 13Desember 1957 yang menyatakan;

Bahwa segala perairan di sekitar, di antara dan yang menghubungkan pulaupulau atau bagian-bagian pulau-pulau yang termasuk daratan Negara Republik Indonesia, dengan tidak memandang luas dan lebarnya adalah bagian-bagian yang wajar wilayah daratan Republik Indonesia dan dengan demikian merupakan bagian daripada perairan nasional yang berada di bawah kedaulatan mutlak daripada Negara Republik Indonesia. Lalu lintas yang damai melalui perairan-perairan pedalaman ini bagi kapal-kapal asing terjamin selama dan sekedar tidak bertentangan dengan kedaulatan dan keselamatan Negara Indonesia. Penentuan batas laut teritorial yang lebarnya 12 mil yang diukur dari garis-garis yang menghubungkan titik-titik yang terluar dari pulau-pulau Negara Republik Indonesia akan ditentukan dengan Undang-Undang

Prinsip dan konsep yang sangat strategis ini kemudian ditegaskan melalui Undang Undang No.4/PRP/60 sebagaimana telah diubah menjadi UndangUndang Nomor 6 Tahun 1996 tentang Perairan Indonesia. Perkembangan selanjutnya, Indonesia meratifikasi 
UNCLOS 1982 dengan ditebitkannya UU No.17 Tahun 1985. Penetapan Indonesia sebagai negara kepulauan akan membawa dampak pada hak untuk melakukan penarikan garis pangkal lurus kepulauan, sesuai dengan ketentuan UNCLOS 1982 pada Bab IV Pasal 46 yang berbunyi sebagai berikut:

1) "archipelagic State" means a State constituted wholly by one or more archipelagos and may include other islands;

2) "archipelago" means a group of islands, including parts of islands, interconnecting waters and other natural features which are so closely interrelated that such islands, waters and other natural features form an intrinsic geographical, economic and political entity, or which historically have been regarded as such.

Melalui ketentuan di atas, wilayah Indonesia yang terpisah oleh perairan dan terdiri dari ribuan pulau dapat dipersatukan dengan menarik garis pembatas diantara kepulauannya. Namun harus dicermati juga bahwa berbeda dengan perairan pedalaman, wilayah perairan pada negara kepulauan dibatasi dengan kewajiban untuk memberi hak lintas damai (innocent passage) dan hak lintas alur kepulauan.

Penentuan kedaulatan negara kepulauan berdasarkan BAB IV Pasal 49 ayat (1) UNCLOS 1982 yaitu The sovereignty of an archipelagic state extends to the waters enclosed by the archipelagic baselines drawn in accordance with article 47, described as archipelagic waters, regardless of their depth or distance from the coast. Pasal tersebut menyimpulkan bahwa kedaulatan suatu negara kepulauan meliputi juga perairan yang ditutup oleh atau terletak dalam dari garis pangkal lurus kepulauan, yang disebut sebagai perairan kepulauan (Mochtar \& Etty, 2003:179). Diundangkannya UNCLOS 1982 ke dalam UU nomor 17 tahun 1985 dan mengimplementasikanya dalam UU nomor 6 tahun 1996 merupakan sebuah kelanjutan keberhasilan dari citacita penyatuan nusantara dengan menutup laut pedalaman sebagai wilayah kedaulatan melalui Deklarasi Djuanda 13 Desember 1957 yang sebelumnya tidak diterima oleh masyarakat internasional yaitu pada forum International Conference on The Law of The Sea I di Jenewa tahun
1958 dan International Conference on The Law of The Sea II di Jenewa 1960.

Alasan Indonesia menutup laut pedalaman sebagai wilayah kedaulatan didasari tiga hal yaitu pertama, pemerintah Kerajaan Belanda yang berdasarkan hasil Konferensi Meja Bundar harus mengembalikan Irian Barat dalam Jangka waktu satu tahun setelah berakhirnya KMB pada November 1949 mengingkari janji ditandai dengan Angkatan Laut Belanda dengan bebas berlayar di wilayah Irian Barat. Kedua, Territoriale Zee en Maritime Kringen Ordonantie tahun 1939 yang masih berlaku tidak mengakomodasi niat untuk menutup laut Indonesia sebagai kedaulatan Indonesia, karena hanya menetapkan batas territorial Indonesia 3 mil dari masing-masing pulau. Ketiga, putusan Mahkamah Internasional (International Court of Justice/ICJ) terhadap kasus sengketa penangkapan ikan antara Norwegia dan Inggris yang dimenangkan oleh Norwegia. Putusan tersebut berisi bahwa Norwegia memiliki batas teritoral laut sepanjang 12 mil dari titik-titik terluar kepulauannya sehingga Inggris tidak boleh semaunya menangkap ikan di perairan Norwegia (Mochtar Kusumaatmadja, 1978 : 98-104).

Implikasi yuridis ratifikasi UNCLOS 1982, Indonesia berkewajiban mengimplementasikan ketentuan yang berkaitan dengan negara kepulauan secara internal yaitu menyangkut pengaturan lebih lanjut ke dalam peraturan nasional dan secara eksternal yang menyangkut kepentingan negara tetangga dan dunia internasional, antara lain terkait delimitasi wilayah maritim Indonesia. Ramses Amer memberikan definisi delimitasi dan demarkasi, Delimitation is the identification of area which is overlapping and should be determined the border with the neighboring country This process is conducted through the border diplomacy between the two neighboring countries. Apapun yang dimaksud demarkasi adalah the border confirmation which is done following the border determination by the government of neighboring countries (Ramses Amer. 2004: 533-547).

Pasal 47 UNCLOS 1982 mengatur hak negara kepulauan untuk menarik garis pangkal lurus kepulauan, yaitu:

1) An archipelagic State may draw straight archipelagic baselines join- 
ing the outermost points of the outermost islands and drying reefs of the archipelago provided that within such baselines are included the main islands and an area in which the ratio of the area of the water to the area of the land, including atolls, is between 1 to 1 and 9 to 1.

2) The length of such baselines shall not exceed 100 nautical miles, except that up to 3 per cent of the total number of baselines enclosing any archipelago may exceed that length, up to a maximum length of 125 nautical miles.

3) The system of such baselines shall not be applied by an archipelagic State in such a manner as to cut off from the high seas or the exclusive economic zone the territorial sea of another State.

4) If a part of the archipelagic waters of an archipelagic State lies between two parts of an immediately adjacent neighboring State, existing rights and all other legitimate interests 18 which the latter State has traditionally exercised in such waters and all rights stipulated by agreement between those States shall continue and be respected.

5) The baselines drawn in accordance with this article shall be shown on charts of a scale or scales adequate for ascertaining their position. Alternatively, lists of geographical coordinates of points, specifying the geodetic datum, may be substituted.

6) The archipelagic State shall give due publicity to such charts or lists of geographical coordinates and shall deposit a copy of each such chart or list with the Secretary- General of the United Nations.

Pasal 47 UNCLOS 1982 juga mengatur ketentuan ditariknya garis pangkal lurus kepulauan dan diatur dalam regulasi nasional yaitu :

1) Pasal 5 ayat (1) dan (3) UU Nomor 6 tahun 1996 Tentang Perairan Indonesia

(1) Garis pangkal kepulauan Indonesia ditarik dengan menggunakan garis pangkal lurus kepulauan.
(2) Garis pangkal lurus kepulauan sebagaimana dimaksud dalam ayat (1) adalah garis -garis lurus yang menghubungkan titik-titik terluar pada garis air rendah pulau-pulau dan karang- karang kering terluar dari kepulauan Indonesia.

2) Pasal 3 PP 38 Tahun 2002 tentang Daftar Koordinat Geografis Titik-titik Garis Pangkal Kepulauan Indonesia.

(1) Di antara pulau-pulau terluar, dan karang kering terluar kepulauan Indonesia, garispangkal untuk mengukur lebar laut teritorial adalah Garis Pangkal Lurus Kepulauan.

(2) Garis Pangkal Lurus Kepulauan sebagaimana dimaksud dalam ayat (1) adalah garis lurus yang menghubungkan titik-titik terluar pada Garis Air Rendah pada titik terluar pulau terluar, dan karang kering terluar yang satu dengan titik terluar pada Garis Air Rendah pada titik terluar pulau terluar, karang kering terluar yang lainnya yangberdampingan.

(3) Panjang Garis Pangkal Lurus Kepulauan sebagaimana dimaksud dalam ayat (2) tidak boleh melebihi 100 (seratus) mil laut, kecuali bahwa 3\% (tiga per seratus) dari jumlah keseluruhan Garis Pangkal Lurus Kepulauan dapat melebihi kepanjangan tersebut, hingga maksimum 125 (seratus dua puluh lima) mil laut.

(4) Penarikan Garis Pangkal Lurus Kepulauan sebagaimana dimaksud dalam ayat (2) dan ayat (3) dilakukan dengan tidak terlalu jauh menyimpang dari konfigurasi umum kepulauan.

(5) Penarikan Garis Pangkal Lurus Kepulauan sebagaimana dimaksud dalam ayat (2) dapat dilakukan dengan memanfaatkan titik-titik terluar pada Garis Air Rendah pada setiap elevasi surut yang di atasnya terdapat suar atau instalasi serupa yang secara permanen berada di atas permukaan air atau elevasi surut yang sebagian atau seluruhnya 
terletak pada suatu jarak yang tidak melebihi lebar laut teritorial dari Garis Air Rendah pulau terdekat.

(6) Perairan yang terletak pada sisi dalam Garis Pangkal Lurus Kepulauan sebagaimana dimaksud dalam ayat (1) adalah Perairan Kepulauan dan perairan yang terletak pada sisi luar Garis Pangkal Lurus Kepulauan tersebut adalah Laut Teritorial"

Dengan demikian, dasar yuridis tersebut merupakan bentuk komitmen Indonesia dalam meratifkasi UNCLOS 1982 dan menjadi landasan hukum bagi Indonesia untuk mempertegas luas wilayah Indonesia, terkait dengan konsekuensi hak dan kewajibannya.

3. Persoalan Batas Maritim Wilayah Indonesia-Malaysia

a. Sengketa Pulau Sipadan dan Ligitan

Pada tahun 1969 Indonesia dan Malaysia sepakat menetapkan status quo atas kedua pulau sengketa. Pada bulan Agustus 1969 Malaysia melebarkan luas laut wilayahnya dari 3 mil menjadi 12 mil dan 10 tahun kemudian Malaysia mempublikasi Peta Baru (dikenal dengan peta 1979) secara unilateral (Bambang Susanto, 2004 : 44-46). Dalam peta Malaysia 1979, Malaysia memasukkan keberadaan pulau Sipadan dan Ligitan serta Karang Unarang ke dalam wilayahnya, yaitu dengan menarik garis dasar median antara garis dasar Malaysia dan garis dasar perairan Indonesia (berdasarkan Prp 4 /1960) hingga sampai ke daerah eksplorasi migas Indonesia di Blok Bukat dan blok Ambalat (Suryo Sakti Hadiwijojo, 2009 : 179).

Sengketa tersebut dibawa ke International Court of Justice dikarenakan mekanisme penyelesaian secara diplomatik tidak mencapai kesepakatan (Bryan Taylor Summer, 2004 : 54). Dengan argumentasi Malaysia yang didukung dengan bukti tindakan berupa kontrol dengan memberlakukan pajak pengumpulan telur penyu di kedua pulau tersebut yang mengacu kepada Turtle Preservation Ordinance tahun 1917-1950, pelestarian satwa burung dan pembangunan mercusuar awal tahun 1960 dianggap Mahkamah merupakan bentuk effective occupation (Ayub Torry SK, 2010 : 320). Sehingga pada tanggal 17 Desember 2002 Mahkamah Internasional memutuskan Pulau dan dan Ligitan menjadi bagian dari kedaulatan Malaysia. Kasus serupa terjadi di wilayah laut Sulawesi, pembagian batas wilayah maritim sampai saat ini belum jelas, begitu juga mengenai Ambalat. Telah terdapat eksplorasi minyak bumi pada Landas Kontinen laut Sulawesi tahun 1960 yaitu berupa pemberikan konsesi minyak oleh Indonesia kepada perusahaan asing dan konsesi minyak tersebut tidak diprotes oleh Malaysia. Adapun Malaysia juga melakukan tindakan serupa dalam mengklaim wilayah Laut Sulawesi yaitu dengan peta yang telah dibuat oleh Kerajaan Malaysia pada tahun 1979, namun peta tersebut telah diprotes oleh delapan negara-negara Asia Tenggara. Hal yang patut diperhitungkan juga adalah dengan kepemilikan secara sah Pulau Sipadan dan Pulau Ligitan, Malaysia seakan-akan mengklaim sebagai negara kepulauan. Implikasi hukum negara kepulauan adalah penghitungan batas wilayah negara sesuai dengan ketentuan UNCLOS 1982 yaitu dengan diukur dari titik paling luar 12 mil pada waktu air surut. Namun, Sipadan dan Ligitan bukan merupakan daratan alamiah dari Borneo sehingga tidak dapat dasar dijadikan Malaysia sebagai dasar negara kepulauan.

Dimenangkannya sengketa SipadanLigitan oleh Malaysia serta kemerdekaan Timor Leste mengakibatkan Indonesia harus membuat regulasi baru tentang delimitasi dan demarkasi wilayah Indonesia. Kebijakan tersebut dilakukan dengan merevisi Peraturan Pemerintah No 38 tahun 2002 tentang Daftar Koordinat Geografis Titik-titik Garis Pangkal Kepulauan Indonesia dengan PP 37 tahun 2008 yaitu dengan merevisi keberadaan Sipadan dan Ligitan sebagai titik dasar Kepulauan Indonesia dan perubahan kongfigurasi titik dasar di sekitar Pulau Timur karena kemerdekaan Timor Leste (Mirza Satria Buana, 2007 : 42).

Regulasi tersebut telah memberikan kejelasan wilayah perairan Indonesia sebab urgensi garis pangkal tidak hanya untuk mengukur lebar laut teritorial tetapi juga berlaku sebagai dasar pengukuran lebar wilayah Zona Ekonomi Eksklusif dan 
landas kontinen suatu negara. Sesuai Pasal 47 UNCLOS 1982, sebagai negara kepulauan Indonesia berhak menarik garis pangkal lurus kepulauan yang menghubungkan titik-titik terluar pulau-pulau dan karang kering terluar kepulauan.

b. Isu dan Permasalahan Pengelolaan Kawasan Perbatasan

Permasalahan yang sering muncul di wilayah perbatasan adalah kebijakan pemerintah yang belum berpihak kepada kawasan-kawasan tertinggal dan terisolir, belum adanya kebijakan dan strategi nasional pengembangan kawasan perbatasan (Ayub Torry SK, 2010 : 324). Hal tersebut menimbulkan paradigma kawasan perbatasan sebagai halaman belakang, terjadinya kesenjangan pembangunan dengan negara tetangga, sarana dan prasarana masih minim, tingginya angka kemiskinan dan jumlah keluarga pra-sejahtera, terisolasinya kawasan perbatasan akibat rendahnya aksesibilitas menuju kawasan perbatasan, rendahnya kualitas Sumber Daya Masyarakat (SDM), adanya aktivitas pelintas batas tradisional, permasalahan Batas Zona Ekonomi Eksklusif (ZEE). Menurut penulis akar permasalahan batas maritim Indonesia-Malaysia adalah kurangnya pengelolaan dan pemeliharaan secara efektif wilayah perbatasan baik itu pulau-pulau terluar maupun batas darat.

\section{Solusi Penyelesaian Sengketa dalam} Penentuan Batas Wilayah Maritim

Hukum Internasional mengenal dua macam jenis sengketa, yaitu sengketa hukum (judicial disputes) dan sengketa politik (political disputes). Perbedaan tersebut mempunyai konsekuensi logis terkait model penyelesaiannya. Penyelesaian sengketa internasional dapat dilakukan dengan dua cara yaitu secara damai dan perang (Huala Adolf, 2004:1). Secara sederhana dua mekanisme tersebut dijabarkan sebagai berikut.

a. Secara damai :

1) Litigasi : Aribitrase internasional dan pengadilan internasional (melalui Internasional Court of Justice dan International Criminal Court)

2) Non Litigasi : negosiasi, mediasi, jasa baik, konsiliasi, penyelidikan, penemuan fakta, penyelesaian regional, penyelesaian dibawah wibawa PBB (Pasal 33 Piagam PBB). b. Melalui kekerasan yaitu retorsi, reprisal (pembalasan), blokade masa damai, dan perang. Pasal 51 Piagam PBB memungkinkan penggunaan kekerasaan dalam penyelesaian sengketa dengan alasan self defence. Pasal 39 Piagam PBB mengatur kewenangan Dewan Keamanan PBB memberikan rekomendasi dan memutuskan tindakan dalam penyelesaian sengketa.

Menurut penulis untuk membedakan kedua jenis sengketa bergantung dari obyek sengketa. Pasal 2 ayat (3) Piagam Perserikatan Bangsa-Bangsa (PBB) menyatakan all members shall settle their international disputes by peaceful means in such manner that international peace and security are not endangered. Pasal tersebut mengandung prinsip iktikad baik (Good Faith), dan larangan penggunaan kekerasan. Dalam kasus sengketa batas wilayah antara Indonesia-Malaysia, penulis tidak membedakan jenis sengketa tersebut. Hal tersebut mengacu pendapat Oppenheim dan Hans Kelsen yang dikutip Huala Adolf bahwa All disputes have their political aspects by the very fact that they concern relation between sovereign states. Disputes which, according to the distinction, are said to be of a legal nature might involve highly important political interests of the states concerned; conversely, disputed reputed according to that distinction to be a political character more often than not concern the application of a principle or a norm of international law (Huala Adolf, 2004 : 6). Pendapat tersebut bermakna setiap sengketa memiliki aspek politis dan hukum. Sehingga dalam penyelesaian sengketa yang memiliki sifat hukum kemungkinan terdapat aspek politis yang dapat diterapkan, ataupun dalam sengketa yang memiliki sifat politis penerapan prinsip-prinsip hukum internasional dapat terjadi.

Menurut penulis solusi penyelesaian sengketa Indonesia-Malaysia dilakukan dengan menekankan pendekatan diplomatik melalui negosiasi dan harus didasarkan pada UNCLOS 1982. Hal tersebut dikarenakan kedua negara telah meratifikasi UNCLOS 1982. Menurut UNCLOS 1982 Pulau Borneo memiliki hak teritorial sejauh 12 mil laut, zona tambahan sejauh 24 mil laut, serta ZEE sejauh 200 mil laut. Secara sederhana terdapat dua bagian di Pulau Borneo, yaitu 
utara yang merupakan wilayah Malaysia dan selatan yang merupakan wilayah Indonesia. Pembagian kedua wilayah tersebut melalui Pulau Sebatik, yang dapat dijadikan sebagai titik awal batas wilayah maritim. Pasal 83 ayat (1) UNCLOS 1982 menekankan pembagian wilayah secara adil (equitable solution).

Equitable solution dilakukan dengan negoisasi membuat bilateral agreement untuk menentukan garis tunggal dalam penentuan batas wilayah maritim negara. Penentuan garis batas wilayah maritim dapat ditempuh dengan menarik garis sementara (garis ekuidistan) yang menggunakan prinsip sama jarak (equity principle) dengan mempertimbangkan faktor yang relevan dengan kemungkinan memodifikasi garis sama jarak tersebut dengan pendekatan diplomatik kedua negara (I Made Andi Arsana, 2007 : 46). Solusi tersebut dikenal dengan istilah two stage approach dan telah diaplikasikan dalam beberapa kasus batas wilayah antara Libya-Malta dan Greenland-Jan Mayen (Churchill and Lowe, 1999 : 187).

Pasal 74 dan 83 UNCLOS 1982, mengatur kriteria mengenai delimitasi ZEE dan landas kontinen antara negara yang pantainya bersebelahan atau berseberangan memiliki beberapa elemen yaitu dengan perjanjian (by agreement) berdasarkan sumber-sumber hukum internasional, seperti tercantum dalam Pasal 38 Statuta Mahkamah Internasional demi tercapainya equitable solution. Rumusan equity principle tidak menentukan metode tertentu namun hanya mensyaratkan adanya equitable solution. Hal tersebut berbeda dengan rumusan Pasal 6 Konvensi Landas Kontinen 1958 yang merumuskan melalui perjanjian, pertimbangan special circumtances atau dengan median line atau equidistance principle. Pengertian special circumtances hanya terbatas pada aspek geografi seperti konfigurasi pantai, keberadaan pantai, keberadaan pulau dan karang serta jalur pelayaran. Menurut Churchil dan Lowe (Onuma Yasuaki, 2003

: 23) relevant circumtances, memiliki lingkup yang lebih luas yaitu :

a. Geographical and geomorphological circumtances

b. The location of the land frontier and advance maritime boundaries c. Historic rights

d. Economic circumstances

Solusi lain, disamping negosiasi dengan bilateral agreement menggunakan penentuan garis ekuidistan, penyelesaian sengketa batas wilayah kedua negara dapat menggunakan mekanisme Association South Eeast Asian Nation (ASEAN). Pasal 22 ayat (1) Piagam ASEAN 2007 mengatur prinsip penyelesaian sengketa secara damai melalui dialog, konsultasi dan negoisasi. Pasal 23 Piagam ASEAN mengatur penyelesaian sengketa yaitu menggunakan mediasi ataupun jasa baik, dengan pihak ketiga Sekjen ASEAN atau negara anggota ASEAN lainnya. Menurut penulis Malaysia tidak akan mudah sepakat membawa sengketa batas wilayah negara ke ASEAN, mengingat Malaysia bersengketa dengan hampir semua negara di Asia Tenggara terkait dengan Peta Malaysia 1979. Penyelesaian di luar pengadilan merupakan pilihan pertama, karena putusan Mahkamah Internasional bersifat final dan mengikat. Jika sengketa memang harus diselesaikan dengan mekanisme litigasi melalui Mahkamah Internasional, maka putusan harus mempertimbangkan equitable principle dengan mempertimbangkan relevant circumtances seperti halnya kasus Tunisia-Libia 1982 (Mark B. Feldman. 1982: 30). Menurut penulis, dengan mempertimbangkan relevant circumstances kualitas putusan Mahkamah Internasional dapat memenuhi aspek kepastian dan keadilan karena tidak hanya berdasar pada aspek yuridis formal namun juga mempertimbangakan aspek geogafi, sejarah, ekonomi dan geomorfologi.

\section{Simpulan}

Alternatif penyelesaian sengketa batas wilayah Indonesia-Malaysia dapat dilakukan dengan, pertama, mengacu pada UNCLOS 1982 melalui Bilateral Mutual Agreement dalam menarik garis sementara (garis ekuidistan) yang menggunakan prinsip sama jarak (equity principle) dan mempertimbangkan faktor yang relevan serta kemungkinan memodifikasi garis sama jarak tersebut dengan pendekatan diplomatik kedua negara, kedua, melalui mekanisme ASEAN, dan . ketiga, melalui mekanisme Mahkamah Interanasional dengan mengedepankan equitable principle dan relevant circumstances. 


\section{Daftar Pustaka}

Ayub Torry Satriyo Kusumo.2010. Optimalisasi Pengelolaan Pulau-Pulau Terluar dalam Rangka Mempertahankan Keutuhan Negara Kesatuan Republik Indonesia. Jurnal Dinamika Hukum. Vol 10 No. 3 September 2010. Purwokerto : UNSOED

Bambang Susanto. 2004. "Kajian Yuridis Permasalahan Batas Maritim Wilayah laut Republik Indonesia (Suatu Pandangan TNI AL Bagi Pengamanan Batas wilayah Laut RI)". Indonesian Journal of Interna- tional Law Special Edition December 2004 National Jurisdiction at Sea.

Brian Taylor Sumner. 2004. Territorial Disputes at the International Court of Justice, Duke Law Journal 2004. Vol $53^{\text {th }}$.

Churchill, R. dan Lowe, A. 1999. The Law of The Sea. Manchester : Manchester University Press.

Gillian Triggs. 2009. "Maritime Boundary Disputes of the South China Sea: International Legal Issues". Legal Studies Research Paper No. 09/37. May 2009. Sidney: Law School. University of Sidney.

Huala Adolf. 2004. Hukum Penyelesaian Sengketa Internasional. Bandung : Sinar Grafika.

I Made Andi Arsana. 2007. Batas Maritim Antar Negara. Suatu Tinjauan Teknis dan Yuridis. Yogyakarta: Gadjah Mada University Press

I Wayan Parthiana. 2003. Pengantar Hukum Internasional. Bandung: Mandar Maju.

Jawahir Thontowi. 2006. Hukum Internasional Kontemporer. Bandung : Refika Aditama.

KML Tobing. 1987. Perjuangan Politik Bangsa Indonesia : Konferensi Meja Bundar. Jakarta : CV Haji Masagung.

Mark B Feldman. 1982. The Tunisia-Libya Continental Self Case : Geographic Justice or Judicial Compro- mise. The American Journal of International Law. Vol 77. Number 2. http://www.jstor.org/discover/10.2307/2200851 ?uid=2129\&uid=2\&uid=70\&uid=4\&sid=2110143 331266316 Juli 2011].

Mirza Satria Buana. 2007. Hukum Internasional Teori dan Praktek. Banjarmasin : FH Ulam Press. Mochtar Kusumaatmadja. 1978. Hukum Laut Internasional. Bandung : Bina Cipta.

Mochtar Kusumaatmadja dan Etty R. Agoes. 2003. Pengantar Hukum Internasional. Bandung : Alumni.

OnumaYasuaki. 2003. "International Law in and with International Politics : The Function of InternationalLaw in International Society”. European Journal of International Law. Vol 14 No. 1.

Shaw, Malcolm N. 1997. International Law. Cambridge : Cambridge University Press.

Suryo Sakti Hadiwijoyo. 2009. Batas Wilayah Negara Indonesia Dimensi, Permasalahan, dan strategi Penanganan Sebuah Tinjauan Empiris dan Yuridis. Yogyakarta : PT Gava Media. 